\title{
The Importance of Estimation Method Choice for the Analysis of the Determinants of Capital Structure: The Example of Poland ${ }^{1}$
}

\author{
Natalia Szomko ${ }^{2}$ \\ Received: 07/03/2017; Revised: 03/04/2017; Accepted: 15/05/2017
}

\begin{abstract}
When assessing the influence of selected factors on capital structure, the researcher has to choose the set of determinants taken into account, their measurability and the estimation method for regression model. However, as shown by this data set, the results vary significantly when the model is estimated with ordinary least squares, fixed effects or generalized method of moments. Taking into account the properties of the data describing capital structure and its determinants, generalized method of moments should be the first choice for the model in question. As generalized method of moments estimators can easily generate invalid results, it is necessary to assess the validity of the model with suitable tests. This study compares the results of parameter and standard errors estimates for the capital structure models. Lagged debt ratio and size have positive impact on debt ratio while profitability, business risk and industry median debt ratio have negative impact for companies listed in Poland.
\end{abstract}

Keywords: capital structure, debt ratio, generalized method of moments.

JEL Codes: G3, G32

\footnotetext{
${ }^{1}$ The research project was financed by the Collegium of World Economy, Warsaw School of Economics from the grant-in-aid for research and development of young researchers and doctoral studies participants for year 2016.

${ }^{2}$ Collegium of World Economy, Warsaw School of Economics, Poland. natalia.szomko@ doktorant.sgh.waw.pl
} 


\section{Introduction}

Although the decisions considering capital structure of the companies are very complex, they are one of the most important financial decisions affecting the performance of the company. Therefore it is important for the researchers to understand the mechanics of capital structure and its determinants. There are two principal theories explaining which factors may influence the choice of financing sources: the pecking order theory and the trade-off theory.

The static pecking order theory, introduced by Myers (1984) and Myers and Majluf (1984), claims that there is a strict preference between the financing sources. Internal sources are the first being used, and afterwards the company turns to external sources. When it comes to the latter, additional debt is preferred, while increase in stockholders' equity is considered as a last resort. The capital structure can be therefore viewed as a result of previous decisions concerning the choice of financing sources (Shyam-Sunder and Myers, 1999). In the dynamic version of pecking order theory, it is possible for the preferences stated above to change depending on the situation on capital markets and valuation of the company (Lucas and McDonald, 1990).

According to the trade-off theory, a company has an optimal capital structure, which balances the positive and negative influence of debt on the value of the company (Huang and Ritter, 2009). Among the advantages of debt, the most important is tax shield, which increases profitability and value of the company. However, increasing debt may lead to higher costs of financial distress, i.e. direct and indirect costs of bankruptcy, lack of financial elasticity or the necessity to cut the dividends (Frank and Goyal, 2009). In the static trade-off theory, the target capital structure of the company is fixed, while the deviations from this target are only temporary (Myers, 2003). In the dynamic version of the theory, the target itself may vary due to changes in company's financial situation, therefore the deviations from the target may be observed for longer periods of time (Leary and Roberts, 2005).

Taking into consideration empirical research concerning capital structure, there are three main questions asked by the researchers: related to the choice of the financing source, related to the determinants of capital structure, and comparing the research methods and statistical tests.

The research concerning the choice of financing sources focuses on the identification of the set of factors influencing the decision in question. These studies include mainly external sources of financing. The choice between equity issue and bond issue was analyzed by Mande, Park and Son (2012). Gozzi, Levine and Schmukler (2010) studied the decision to use external equity financing in comparison with other sources, while D'Mello and Miranda (2010) described the companies that decided to use debt financing for the first time. Other studies analyzed the determinants of the choice of external source of financing (e.g. Hale, 2003).

As far as capital structure determinants are concerned, their goal is to identify a set of factors affecting debt ratios of the companies. The most prominent studies include Rajan and Zingales (1995), Frank and Goyal (2009), Lemmon, Roberts and Zender (2008) and Huang and Ritter (2009). As Elsas and Florysiak (2008) claim, the set of determinants identified by Rajan and Zingales (2995) should be pointed as fundamental: these are tangibility of assets, growth possibilities, size and profitability.

The studies concerning research methods are based on both the data concerning companies and the data generated in simulations. Their main purpose is to assess if the methods suggested by other researchers allow differentiating between the companies having target capital structure and those making financing choices in line with the pecking order 
theory. Such studies include, among others, Lemmon and Zender (2010), Leary and Roberts (2010) and Chang and Dasgupta (2009).

The aim of this study is to compare the direction and magnitude of the impact of selected factors on capital structure of companies listed in Warsaw Stock Exchange depending on the estimation method chosen for the regression model. There were three estimators used in the study: ordinary least squares (OLS), fixed effects (FE) and generalized method of moments (GMM). As far as explanatory variables are concerned, the chosen set of factors include profitability, size, growth possibilities, tangibility of assets, business risk and industry median debt ratio.

It should be underlined that previous research concerning capital structure determinants did not reach consensus concerning the set of factors that affects debt ratios. Apart from the fundamental explanatory variables listed above, there is a large number of studies adding further variables to the set of possible determinants. Moreover, there are numerous measures for the identified factors used in previous studies. Adding to this the differences in research methods, the results concerning the direction of the impact of selected factors on capital structure, its magnitude and significance differ widely between the studies.

Further, more detailed research concerning capital structure of the companies brings us closer to the understanding of the mechanisms of capital structure formation. As a consequence, it becomes possible to assess the choices of financing sources made by companies and its impact on the value for the shareholders.

As far as studies of companies operating in Poland are concerned, although their number is moderate, they are mainly fragmented. Most of the studies use simple statistical methods (descriptive statistics, correlation analysis, multiple regression models estimated with OLS or FE). The study in question complements previous research for polish companies, enabling the comparison of the capital structure determinants for companies operating in Poland as a developing country and factors identified as important for the developed countries.

The rest of the paper is structured as follows. In section 2. there are presented the main factors influencing capital structure of the companies, identified on the basis of both theoretical and empirical research. Section 3. expands on the assumptions of estimation methods used for capital structure models, as well as consequences of their violations. In section 4. The data set is described. Section 5. focuses on the estimates of regression models explaining debt ratios of companies listed on Warsaw Stock Exchange, together with the discussion of the results. The last section concludes.

\section{Determinants of Capital Structure}

The capital structure theories described above differ not only in the set of factors which influences the capital structure, but also in the direction of this influence. According to the pecking order theory, tangibility of assets, profitability, liquidity and business risk should have negative influence on the amount of debt used by the company, whereas the influence of growth possibilities, size and payment of dividends should be positive (Mazur, 2007). The static trade-off theory disagrees when it comes to tangibility, profitability and liquidity (positive influence), while the influence of growth possibilities should be negative. Both theories agree on the impact of size and business risk. Moreover, the static trade-off theory predicts that the company uses more debt when it faces higher tax rate, when its products are less unique and when it has lower value of non-debt tax shield (Mazur, 2007). 
Table 1: Capital structure determinants described in selected empirical research

\begin{tabular}{|c|c|c|c|c|c|c|c|c|c|c|c|c|c|c|c|}
\hline & 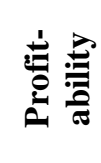 & 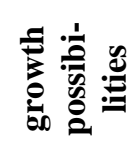 & . & 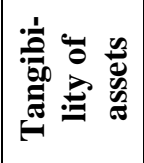 & 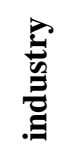 & $\vec{a}$ & $\begin{array}{l}\stackrel{\partial ્ 0}{\simeq} \\
\simeq\end{array}$ & 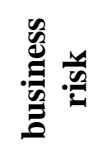 & 莺 & 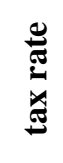 & $\stackrel{?}{:}$ & 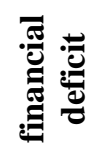 & 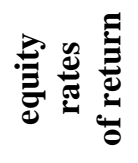 & 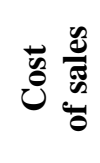 & 응 \\
\hline Anderloni and Tanda (2014) & & & & & & & & & $\mathrm{X}$ & $\mathrm{X}$ & & & $\mathrm{X}$ & & \\
\hline Chang and Dasgupta (2009) & $\mathrm{X}$ & $\mathrm{X}$ & $\mathrm{X}$ & $\mathrm{X}$ & & & $\mathrm{X}$ & & & & & & & & \\
\hline Chang, Chou and Huang (2014) & & & & & & & & & & & & & & & $\mathrm{X}$ \\
\hline Dang, Kim and Shin (2012) & $\mathrm{X}$ & $\mathrm{X}$ & $\mathrm{X}$ & $\mathrm{X}$ & & $\mathrm{X}$ & & & & & & $\mathrm{X}$ & & & \\
\hline De Jong, Kabir and Ngyuen (2008) & $\mathrm{X}$ & $\mathrm{X}$ & $\mathrm{X}$ & $\mathrm{X}$ & & & & $\mathrm{X}$ & & & & & & & \\
\hline De Jong, Kabyr and Nguyen (2008) & & & & & & & & & & & $\mathrm{X}$ & & & & \\
\hline DeJong, Kabir and Nguyen (2008) & & & & & & & & & & $\mathrm{X}$ & & & & & \\
\hline Elsas and Florysiak (2008) & $\mathrm{X}$ & $\mathrm{X}$ & & & & & & & & & & & & & \\
\hline Farhat, Cotei and Abugri (2009) & $\mathrm{X}$ & & $\mathrm{X}$ & $\mathrm{X}$ & & $\mathrm{X}$ & & & & & & & & & \\
\hline Faulkender et al. (2012) & $\mathrm{X}$ & $\mathrm{X}$ & $\mathrm{X}$ & $\mathrm{X}$ & $\mathrm{X}$ & $\mathrm{X}$ & $\mathrm{X}$ & & & & & & & & \\
\hline Flannery and Rangan (2006) & $\mathrm{X}$ & $\mathrm{X}$ & $\mathrm{X}$ & $\mathrm{X}$ & $\mathrm{X}$ & $\mathrm{X}$ & $\mathrm{X}$ & & & & & & & & $\mathrm{X}$ \\
\hline Frank and Goyal (2009) & $\mathrm{X}$ & $\mathrm{X}$ & $\mathrm{X}$ & $\mathrm{X}$ & & & & & & & & & & & \\
\hline Haron $(2014)$ & & & & & & & & & & & & & $\mathrm{X}$ & & \\
\hline $\begin{array}{l}\text { Hovakimian, Hovakimian and } \\
\text { Tehranian (2004) }\end{array}$ & $\mathrm{X}$ & $\mathrm{X}$ & $\mathrm{X}$ & $\mathrm{X}$ & $\mathrm{X}$ & & $\mathrm{X}$ & & & & & & & $\mathrm{X}$ & \\
\hline Huang and Ritter (2009) & $\mathrm{X}$ & & $\mathrm{X}$ & $\mathrm{X}$ & & & $\mathrm{X}$ & & & & & & & & \\
\hline Kayhan and Titman (2007) & $\mathrm{X}$ & $\mathrm{X}$ & $\mathrm{X}$ & $\mathrm{X}$ & $\mathrm{X}$ & & $\mathrm{X}$ & & & & & & & $\mathrm{X}$ & \\
\hline LaRocca et al. (2009) & $\mathrm{X}$ & $\mathrm{X}$ & $\mathrm{X}$ & $\mathrm{X}$ & & $\mathrm{X}$ & & & & & & & & & \\
\hline Leary and Roberts (2005) & & $\mathrm{X}$ & $\mathrm{X}$ & $\mathrm{X}$ & $\mathrm{X}$ & $\mathrm{X}$ & & $\mathrm{X}$ & & & & & & $\mathrm{X}$ & \\
\hline Lemma and Negash (2014) & & & & & & & & & $\mathrm{X}$ & & & & & & \\
\hline Lemmon, Roberts and Zender (2008) & $\mathrm{X}$ & $\mathrm{X}$ & $\mathrm{X}$ & $\mathrm{X}$ & $\mathrm{X}$ & & & $\mathrm{X}$ & $\mathrm{X}$ & & & & & & \\
\hline MacKay and Phillips (2005) & $\mathrm{X}$ & $\mathrm{X}$ & $\mathrm{X}$ & & & & & $\mathrm{X}$ & & & & & & & \\
\hline Oztekin and Flannery (2012) & & & & & & & & & & & $\mathrm{X}$ & & & & \\
\hline Öztekin and Flannery (2012) & $\mathrm{X}$ & $\mathrm{X}$ & $\mathrm{X}$ & $\mathrm{X}$ & $\mathrm{X}$ & $\mathrm{X}$ & $\mathrm{X}$ & & & & & & & & \\
\hline Rashid (2014) & & & & & & & & & & & & $\mathrm{X}$ & $\mathrm{X}$ & & \\
\hline Santos, Moreira and Vieira (2014) & & & & & & & & & & $\mathrm{X}$ & & & & & \\
\hline
\end{tabular}

Source: Author's own work. 
Considering the results of the empirical research conducted in the field of capital structure determinants, there is consensus concerning neither the set of the factors, not the direction of their impact on companies' debt ratios. Taking into account selected studies presented in Table 1, the most often included capital structure determinants are: profitability, growth possibilities, size, tangibility of assets, industry, non-debt tax shield, R\&D expenditures and business risk. Moreover, several studies analyzed also the impact of such factors as: dividend payments, tax rate, liquidity, financial deficit, equity rates of return, cost of sales and rating of company's debt.

Most of the studies start from the set of determinants analyzed by Rajan and Zingales (1995), who included growth possibilities, profitability, tangibility and size. A broader set of factors was analyzed by Harris and Raviv (1992), who considered also non-debt tax shields, investment opportunities, earnings volatility, default risk, advertising expenditures, R\&D expenditures, and product uniqueness. A thorough examination of factors suggested by the previous research was conducted by Frank and Goyal (2009), who concluded that apart from the determinants suggested by Rajan and Zingales (1995), median industry debt ratio and expected inflation should be also taken into account.

As can be seen in Table 2, in the empirical research concerning companies operating in Poland, there was a similar set of determinants used most often: profitability, tangibility of assets and size. Moreover, liquidity and age of the company were also popular. Other capital structure determinants suggested by previous research include growth possibilities, non-debt tax shield, information asymmetry measures, shareholder structure and product uniqueness.

Table 2: Capital structure determinants described in selected empirical research for companies operating in Poland.

\begin{tabular}{|c|c|c|c|c|c|c|c|c|c|c|}
\hline & 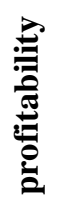 & 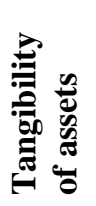 & 芯 & 胥 & 范 & 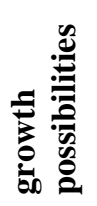 & 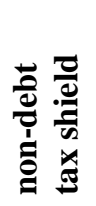 & 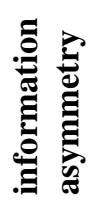 & 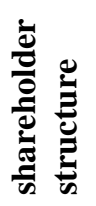 & 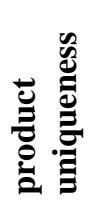 \\
\hline Adrian (2010) & $\mathrm{X}$ & $\mathrm{X}$ & & $\mathrm{X}$ & & & & & & \\
\hline Barowicz (2012) & & & & & & & & & & $\mathrm{X}$ \\
\hline Barowicz (2013) & $\mathrm{X}$ & $\mathrm{X}$ & $\mathrm{X}$ & & & & & & & \\
\hline Czapiewski and Kubiak (2015) & & & & & & & & $\mathrm{X}$ & & \\
\hline De Haas and Peters (2004) & $\mathrm{X}$ & & $\mathrm{X}$ & & $\mathrm{X}$ & & $\mathrm{X}$ & & & \\
\hline Delcoure (2007) & $\mathrm{X}$ & $\mathrm{X}$ & $\mathrm{X}$ & & & & & & & \\
\hline Devic and Krstic (2001) & $\mathrm{X}$ & & $\mathrm{X}$ & & & & & & & \\
\hline Gajdka (2002) & $\mathrm{X}$ & $\mathrm{X}$ & & $\mathrm{X}$ & & & $\mathrm{X}$ & & & \\
\hline Gao and Zhu (2012) & & & & & & & & $\mathrm{X}$ & & \\
\hline Jędrzejczak-Gas (2013) & $\mathrm{X}$ & & $\mathrm{X}$ & $\mathrm{X}$ & & & & & & \\
\hline Joever (2012) & $\mathrm{X}$ & $\mathrm{X}$ & $\mathrm{X}$ & & & & & & & \\
\hline Klapper et al. (2006) & $\mathrm{X}$ & $\mathrm{X}$ & & & $\mathrm{X}$ & & & & & \\
\hline Mazur (2007) & $\mathrm{X}$ & $\mathrm{X}$ & $\mathrm{X}$ & $\mathrm{X}$ & & & $\mathrm{X}$ & & & $\mathrm{X}$ \\
\hline Motylska-Kuźma (2013) & & & & & & & & & $\mathrm{X}$ & \\
\hline Socha (2015) & & & & & & & & & $\mathrm{X}$ & \\
\hline Weill (2000) & $\mathrm{X}$ & $\mathrm{X}$ & $\mathrm{X}$ & & $\mathrm{X}$ & & & & & \\
\hline
\end{tabular}

Source: Author's own work.

There were also individual studies including dividend payments (Mazur, 2007), lifecycle stage of the company (Siedlecki, 2012) and innovativeness (Prędkiewicz and Prędkiewicz, 2015). It should also be noted that the results of the previous study on the basis of companies in Poland assessing the determinants of capital structure with GMM method (Białek-Jaworska and Nehrebecka, 2015) concluded that lagged debt ratio, tangibility of assets, liquidity, non- 
debt tax shield, interest tax shield, probability of bankruptcy and currency exchange rates significantly affect the debt ratios of companies operating in Poland. As far as determinants and its measures are concerned, a thorough review can be found in Frank and Goyal (2009) or Kumar et al. (2017).

For this study, the dependent variable is defined as total debt ratio, measured as the relation of book value of total liabilities to the sum of the book value of liabilities and market value of equity. The set of factors used as explanatory variables include profitability, size, growth possibilities, tangibility of assets, business risk and industry median debt ratio.

\section{Estimation Methods Used for Capital Structure Research}

Inconsistent results of previous empirical studies result from differences in several aspects of research plan. Firstly, researchers take into account varying set of factors used as determinants of debt ratios. Secondly, the factors in question are operationalized by various measures. Thirdly, the magnitude and direction of the influence of selected factors on companies' debt ratios might differ depending on the estimation method chosen by the researchers.

Taking into account the estimation methods used to assess the importance of the determinants, among the most popular are OLS estimator and FE estimator. More advanced approaches are generalized methods of moments estimators (GMM), in particular ArellanoBond (1991) estimator, Blundell-Bond (1998) estimator and Hahn et al. (2007) estimator. Selected empirical research using the listed methods is presented in Table 3.

Table 3: Estimation methods used in selected studies concerning capital structure.

\begin{tabular}{|l|c|c|l|l|l|}
\hline & OLS & $\begin{array}{l}\text { Fixed } \\
\text { effect }\end{array}$ & $\begin{array}{l}\text { GMM } \\
\text { Arellano- } \\
\text { Bond } \\
(\mathbf{1 9 9 1})\end{array}$ & $\begin{array}{l}\text { GMM } \\
\text { Blundell- } \\
\text { Bond } \\
(\mathbf{1 9 9 8})\end{array}$ & $\begin{array}{l}\text { GMM } \\
\text { Hahn } \\
\text { al. (2007) } \\
\text { et }\end{array}$ \\
\hline De Jong, Kabir and Nguyen (2008) & $\mathrm{X}$ & & & & \\
\hline Elsas and Florysiak (2009) & $\mathrm{X}$ & $\mathrm{X}$ & $\mathrm{X}$ & & \\
\hline Faulkender et al. (2012) & $\mathrm{X}$ & & & $\mathrm{X}$ & \\
\hline Frank and Goyal (2009) & $\mathrm{X}$ & & & & \\
\hline Hovakimian, Hovakimian and Tehranian (2004) & $\mathrm{X}$ & & & & \\
\hline Kayhan and Titman (2007) & $\mathrm{X}$ & & & & \\
\hline Farhat, Cotei and Abugri (2009) & & $\mathrm{X}$ & & & \\
\hline Flannery and Rangan (2006) & & $\mathrm{X}$ & & & $\mathrm{X}$ \\
\hline Huang and Ritter (2009) & & $\mathrm{X}$ & & & \\
\hline La Rocca et al. (2009) & & $\mathrm{X}$ & $\mathrm{X}$ & & $\mathrm{X}$ \\
\hline Lemmon, Roberts and Zender (2008) & $\mathrm{X}$ & & $\mathrm{X}$ & \\
\hline Öztekin and Flannery (2012); & & & \\
\hline
\end{tabular}

Source: Author's own work.

Influence of the selected determinants of capital structure is assessed on the basis of panel data, where time dimension is significantly smaller than the number of companies. Moreover, debt ratios are characterized by high persistency, i.e. its current realizations are highly correlated with past ones (Roodman, 2006; Wintoki, Linck and Netter, 2012). As far as independent variables are concerned, the factors describing the situation of the company are not strictly exogenous, i.e. they may be correlated with past and current realizations of residuals (Roodman, 2006; Wintoki, Linck and Netter, 2012). Such properties of the data indicate that regression models explaining the companies' debt ratios may suffer from severe biases, resulting in unreliable estimates of both parameters and their standard errors.

Given the characteristics of the debt ratios and their determinants described above, the relation in question should be analyzed with dynamic panel data models (Antoniou, Guney 
and Paudyal, 2008). The estimators for these models are designed to deal with the issues of endogeneity, persistence of dependent variable and two-dimensional residuals (by time and by companies) (Baltagi, 2008). These are, among others, Arellano-Bond (1991) estimator (called "difference GMM", GMM-DIFF), Blundel-Bond (1998) estimator (called "system GMM", GMM-SYS) and Hahn et al. (2007) estimator (called "long-differencing estimator", LD).

When estimating the regression models explaining debt ratios with OLS method, the standard error estimates are biased due to two-dimensional residuals (Baltagi, 2008). Moreover, the parameter estimates themselves are biased and inconsistent due to correlation between lagged dependent variable (used as a regressor in dynamic models) and the residuals (Baltagi, 2008). OLS method does not account for fixed effects for the companies (Antoniou, Guney and Paudyal, 2008). Moreover, OLS requires strict exogeneity of independent variables, which is not true for capital structure determinants (Antoniou, Guney and Paudyal, 2008).

In comparison to OLS, FE estimators take into account the two-dimensional residuals, as well as fixed effects for the companies (Baltagi, 2008). It results in consistent estimates for independent variables, however the parameter estimates for lagged dependent variable and for fixed effects remain biased (Baltagi, 2008). As a consequence, the FE Within estimator is biased, and its consistency depends on large time dimension of the data (Nickell, 1981).

Although both OLS and FE estimators are biased for dynamic panel data, the direction of their bias is opposite. OLS parameter estimates are lower than true parameters, while FE parameter estimates are higher than their true values (Antoniou, Guney and Paudyal, 2008; Wintoki, Linck and Netter, 2012). More accurate estimates can be obtained by using GMMDIFF and GMM-SYS. Both of these estimators are generalized method of moments (GMM) estimators, which use instrumental variables (IV) method. IV method requires identifying a set of variables, called instruments, which are highly correlated with independent variables, but uncorrelated with the residuals (Hurlin, 2010). By eliminating the correlation between dependent variables and residuals, the regression estimates become consistent. As far as GMM estimator is concerned, its parameter estimates are calculated by equating theoretical moments with their empirical counterparts or estimates (Hurlin, 2010). Contrary to the maximum likelihood method of estimation, GMM method does not require the distribution function of the data to be known.

Both GMM-DIFF and GMM-SYS estimators are based on the assumption that there are no external instruments available (Baltagi, 2008). Arellano and Bond (1991) suggested that after first-differencing the equation and eliminating fixed effects, levels of the explanatory variables can be used as instruments for GMM. It has to be noted, however, that such a transformation aggravates the problem of missing data. One of the solutions is to use forward orthogonal deviations transformation (FOD), i.e. to calculate the differences between current value of the variable and average future values of this variable (Roodman, 2006). Another modification, introduced by Blundell and Bond (1998), was to use first differences of variables as instruments for their levels. As a consequence, GMM-SYS is based on both levels and first differences as dependent variables (Roodman, 2006). Then it is possible to include time-invariant variables and use more of the information from the data.

For OLS estimates to be valid, it is necessary to ensure that residuals are uncorrelated, homoscedastic and have normal distribution. GMM estimators do not require these assumptions to hold (Wintoki, Linck and Netter, 2012). However, crucial for both GMMDIFF and GMM-SYS is lack of autocorrelation of second order and higher of residuals (after elimination of fixed effects) (Roodman, 2006). Moreover, GMM estimates are highly dependent on the quality of the instruments (Baltagi, 2008). Weak instruments may result in 
biased estimates, especially if full set of moments is used and their number is high compared to the number of analyzed individuals or companies. The problem of weak instruments is more pronounced for GMM-DIFF estimator, for shorter panels and more persistent data (Antoniou, Guney and Paudyal, 2008).

The GMM assumptions are verified by two tests: Arellano-Bond test of second order autocorrelation and Sargan test of instruments' validity (Baltagi, 2008). The former test's null hypothesis is lack of serial correlation between first differences of the residuals and their values lagged by two periods. The latter test is used to check for joint validity of overidentifying moment conditions. The Sargan test has a tendency to reject the null hypothesis when residuals are heteroskedastic, and its robust variant is Hansen test (Roodman, 2006).

GMM methods may seem like a remedy for all the problems of data on capital structure and its determinants. However it has to be underlined that GMM-DIFF and GMM-SYS are complicated, thus they easily generate invalid estimates (Roodman, 2006). Moreover, asymptotic qualities of the estimators are not a good predictor of their characteristics in finitesample models (Ahn and Schmidt, 1995). It is though possible to check the estimators by using simulated data, based on real capital structure data. Such a study was conducted by, for example, Flannery and Hankins (2013). The authors concluded that estimation with GMMSYS results in reliable parameter estimates regardless of the endogeneity or persistence observed in the sample. GMM-SYS estimator proved to be better than OLS, FE, GMM-DIFF and LD. It should be noted that LD estimator, which was supposed to lower the severity of weak instruments problem in GMM (Hahn et al, 2007), generated 5-fold increase in standard errors when the data were highly persistent (Flannery and Hankins, 2013).

Biased results of OLS estimation are also confirmed by empirical studies based on real data (Deesomsak, Paudyal and Pescetto, 2009; Ozkan, 2001). Another finding is that GMMDIFF estimates of parameter variance are higher than for GMM-SYS (Deesomsak, Paudyal and Pescetto, 2009; Ozkan, 2001). Considering the properties of the data on debt ratios and their determinants, the assumptions of OLS and FE estimators are highly unlikely to be met. As far as GMM methods are concerned, GMM-SYS parameter estimates can be more reliable than GMM-DIFF estimates. However it has to be stressed that due to the complexity of GMM methods, more than one GMM model should be estimated to compare the obtained estimates (Baltagi, 2008).Moreover, it is possible to assess the influence of selected factors on debt ratios only if the models' assumptions are met.

\section{Data and Methodology}

The aim of this study is to analyze the influence of selected factors on debt ratios of companies listed on Warsaw Stock Exchange.

The sample consists in companies listed in continuous system trading in 2002-2015. The financial data of the companies are taken from Notoria Serwis Database. Taking into consideration the nature of companies' sources of financing, the following industries are excluded from the sample: banking, insurance, other financial, capital market and conglomerates. Moreover, in order to guarantee the comparability of the data, the companies whose shares trade in currency other than PLN are excluded. There are 3079 observations for 479 companies included in the sample.

The dependent variable in the study is total debt ratio, defined as ratio of book value of total liabilities to the sum of book value of total liabilities and market value of equity. The market debt ratio was chosen instead of book debt ratio due to its forward-looking character 
and proximity to internal value of the company (Santos, Moreira and Vieira, 2014; Welch, 2004).

As far as capital structure determinants are concerned, the study focuses on the following factors: profitability, size, growth possibilities, tangibility of assets, business risk and industry classification. Profitability is measured with ratio of earnings before interest, taxes, depreciation and amortization (EBITDA) to total assets (e.g. Chang and Dasgupta, 2009; Dang, Kim and Shin, 2012; Kayhan and Titman, 2007; Rashid, 2014). Size of the company is measured by natural logarithm of total assets (e.g. Elsas and Florysiak, 2009; Faulkender et al, 2012; La Rocca et al, 2009; MacKay and Phillips, 2005; Oztekin and Flannery, 2012). Growth possibilities are measured by ratio of market value of equity to book value of equity (e.g. Chang and Dasgupta, 2009; Elsas and Florysiak, 2009; Faulkender et al, 2012; MacKay and Phillips, 2005; Oztekin and Flannery, 2012). Tangibility of assets is measured as ratio of sum of property, plant, equipment and inventory to total assets (e.g. Frank and Goyal, 2009). Business risk is measured as standard deviation of ratio of operating cash flows to total assets, calculated over 3-year period (e.g. MacKay and Phillips, 2005). Industry classification is included in the model by industry median debt ratio as one of independent variables (e.g. Faulkender et al, 2012; Frank and Goyal, 2009; Lemmon, Roberts and Zender, 2008; Oztekin and Flannery, 2012; Rashid, 2014).

The impact of profitability, growth possibilities, tangibility of assets, business risk and industry classification on debt ratios is measured by multiple regression model. The explanatory variables are lagged by one period and include lagged dependent variable. As a consequence, the regression model has the following form:

$$
\begin{aligned}
& y_{i t}=b_{0} y_{i, t-1}+b_{1} x_{1, i, t-1}+b_{2} x_{2, i, t-1}+b_{3} x_{3, i, t-1}+b_{4} x_{4, i, t-1}+b_{5} x_{5, i, t-1}+ \\
& b_{6} x_{6, i, t-1}+b_{7}+\varepsilon_{i, t}
\end{aligned}
$$

where: $\mathrm{y}-$ total debt ratio, $\mathrm{x}_{1}-$ profitability, $\mathrm{x}_{2}-$ size, $\mathrm{x}_{3}-$ growth possibilities, $\mathrm{x}_{4}-$ tangibility of assets, $\mathrm{x}_{5}-$ business risk, $\mathrm{x}_{6}-$ industry median debt ratio, $\mathrm{b}_{0}-\mathrm{b}_{7}-$ parameter estimates, $\varepsilon$ - residuals.

\section{Results and Discussion}

Parameter estimates and their standard errors (in italics) for different estimation methods are presented in Table 4. Model estimated with OLS accounts for possible heteroskedasticity. Robust standard errors are also used with FE estimation. For GMM methods, all possible lags of explanatory variables are included in the model, with robust standard errors and FOD transformation for both GMM-DIFF and GMM-SYS models.

Table 4: Parameter estimates of OLS, FE, GMM-DIFF and GMM-SYS models.

\begin{tabular}{|l|c|c|c|c|}
\hline variable & OLS & FE & GMM-DIFF & GMM-SYS \\
\hline debt ratio & $0.7866^{* *}$ & $0.4406^{* *}$ & $0.4421^{* *}$ & $0.7088^{* *}$ \\
& 0.0163 & 0.0230 & 0.0450 & 0.0300 \\
\hline profitability & $-0.0940^{* *}$ & $-0.0999^{* *}$ & $-0.0582^{*}$ & $-0.0954^{* *}$ \\
& 0.0224 & 0.0176 & 0.0248 & 0.0217 \\
\hline size & $0.0061^{* *}$ & $0.0355^{* *}$ & $0.0368^{*}$ & 0.0056 \\
& 0.0017 & 0.0085 & 0.0148 & 0.0043 \\
\hline growth possibilities & 0.0000 & -0.0004 & -0.0006 & -0.0005 \\
& 0.0002 & 0.0006 & 0.0009 & 0.0007 \\
\hline tangibility of assets & -0.0045 & 0.0545 & 0.0838 & 0.0081 \\
& 0.0118 & 0.0333 & 0.0539 & 0.0269 \\
\hline business risk & 0.0083 & 0.0008 & -0.0229 & -0.0405 \\
& 0.0281 & 0.0344 & 0.0470 & 0.0318 \\
\hline
\end{tabular}




\begin{tabular}{|l|c|c|c|c|}
\hline $\begin{array}{l}\text { industry median debt } \\
\text { ratio }\end{array}$ & 0.0412 & 0.0447 & 0.0574 & 0.0585 \\
\hline constant & 0.0246 & 0.0369 & 0.0515 & 0.0375 \\
\hline $\mathrm{N}$ & $-0.1373^{* *}$ & $-0.2994^{* *}$ & & -0.0976 \\
\hline number of instruments & 0.0335 & 0.1067 & 0.0581 \\
\hline Arellano-Bond test for & 3079 & 3079 & 2653 & 3079 \\
AR(1) & & & 534 & 618 \\
\hline Arellano-Bond test for & & & -7.56 & $(0.000)$ \\
AR(2) & & & $(0.000)$ & 0.57 \\
\hline Arellano-Bond test for & & & 0.35 & $(0.568)$ \\
AR(3) & & & $(0.726)$ & 1.24 \\
\hline Arellano-Bond test for & & & $(0.274)$ & $-0.214)$ \\
AR(4) & & & $(0.356)$ & $(0.359)$ \\
\hline Sargan test & & & 597.84 & 828.89 \\
& & & $(0.006)$ & $(0.000)$ \\
\hline Hansen test & & & $(1.000)$ & 386.21 \\
& & & & $(1.000)$ \\
\hline
\end{tabular}

Source: Author's own work.

Note: Year dummies are included in the estimation for all models. ** - significantly different from zero at 0.01 significance level, * - significantly different from zero at 0.05 significance level.

As it was stated in section 3, both OLS and FE estimates are biased, but the direction of the bias is opposite. Therefore the parameters obtained with GMM estimators, if close to true value, should be higher than OLS estimates, but lower than FE estimates. Moreover, the comparison of OLS, FE and GMM estimates shows the magnitude of the parameter bias.

Lagged total debt ratio has a significant positive impact on total debt ratio according to all the models (at any significance level). However, the magnitude of its impact differs largely between the models - it is the lowest in FE model (0.4406), while the highest for OLS model (0.7865).

Profitability has a negative significant influence on debt ratio for all the models (at significance level 0.05 for GMM-DIFF and at any significance level for other estimators). The impact of this variable also varies considerably depending on the estimator chosen, being the lowest for FE (-0.09988) and the highest for GMM-DIFF (-0.0582).

Size has a significant positive impact on debt ratio for all the models except GMM-SYS (at any significance level). It should be noted, however, that the differences in its parameters are even higher than for lagged debt ratio and profitability. The lowest parameter estimate is produced by GMM-SYS model (0.0056). For GMM-DIFF model the parameter in question is 6 times higher than for GMM-SYS model.

The impact of growth possibilities on debt ratio is not significant, though it is negative for all the models. When it comes to tangibility of assets, its influence on debt ratio is also insignificant. For this explanatory variable parameter estimate is negative for OLS model, while positive for other models. Moreover, negative insignificant impact of business risk on debt ratio was also identified by GMM-DIFF and GMM-SYS models. The impact of industry mean debt ratio was also insignificant, though positive according to all the models.

As far as fixed effects for years are concerned, they were included in the GMM models in order to control for the changes of macroeconomic environment. The parameters for year dummies in both GMM-DIFF and GMM-SYS are not monotonous or close to monotonous. As the magnitude of the parameters in question is not crucial for this study, they will not be thoroughly discussed. 
Comparing parameters' standard errors for models presented in Table 4, the estimates for GMM-SYS are lower than GMM-DIFF standard errors for all explanatory variables. Standard errors for profitability are lower with GMM-SYS than with OLS. Moreover, they are lower than estimated by FE method for size.

The second part of Table 4. presents the results of post-estimation tests for GMM models, i.e. the values of test statistics and its probability values $(\mathrm{Pr}>\mathrm{z}$ for Arellano-Bond tests and Prob>chi 2 for Sargan and Hansen tests). For the GMM-DIFF model, Arellano-Bond test suggest presence of autocorrelation of residuals up to first order (but not of second order and higher), while Hansen test's implausible value of 1.000 suggest that the number of instruments is too large in comparison to number of observations (Roodman, 2006). Therefore the instruments of GMM-DIFF are not valid. The same conclusion is reached on the basis of GMM-SYS tests. In order to improve the properties of instruments, only lags of second order and higher should be used for estimation (Roodman, 2006). The results of fitting the GMMDIFF and GMM-SYS models with instruments lagged two and higher are presented in Table 5. GMM-DIFF1 and GMM-SYS1 include all possible lags from second order, while GMMDIFF2 and GMM-SYS2 are based on, respectively, lags two to four and two to three.

Table 5: Parameter estimates of GMM-DIFF and GMM-SYS models with further lags of instruments.

\begin{tabular}{|c|c|c|c|c|}
\hline variable & GMM-DIFF1 & GMM-DIFF2 & GMM-SYS1 & GMM-SYS2 \\
\hline debt ratio & $\begin{array}{c}0.4889 * * \\
0.0509\end{array}$ & $\begin{array}{c}0.5652^{* *} \\
0.0652\end{array}$ & $\begin{array}{c}0.7549 * * \\
0.0313\end{array}$ & $\begin{array}{c}0.8037 * * \\
0.0367\end{array}$ \\
\hline profitability & $\begin{array}{c}-0.1245 * * \\
0.0441\end{array}$ & $\begin{array}{c}-0.1115 \\
0.0555\end{array}$ & $\begin{array}{c}-0.1180 * * \\
0.0411\end{array}$ & $\begin{array}{c}-0.1232^{*} \\
0.0588\end{array}$ \\
\hline size & $\begin{array}{l}0.0310 \\
0.0161 \\
\end{array}$ & $\begin{array}{c}0.0399 * \\
0.0179\end{array}$ & $\begin{array}{l}0.0073 \\
0.0050\end{array}$ & $\begin{array}{l}0.0044 \\
0.0054\end{array}$ \\
\hline growth possibilities & $\begin{array}{c}-0.0010 \\
0.0014 \\
\end{array}$ & $\begin{array}{r}-0.0015 \\
0.0023 \\
\end{array}$ & $\begin{array}{r}-0.0001 \\
0.0010\end{array}$ & $\begin{array}{c}-0.0001 \\
0.0013\end{array}$ \\
\hline tangibility of assets & $\begin{array}{r}-0.0039 \\
0.0574 \\
\end{array}$ & $\begin{array}{l}0.0108 \\
0.0642 \\
\end{array}$ & $\begin{array}{c}-0.0358 \\
0.0299\end{array}$ & $\begin{array}{c}-0.0324 \\
0.0329\end{array}$ \\
\hline business risk & $\begin{array}{r}-0.0327 \\
0.0419\end{array}$ & $\begin{array}{r}-0.0155 \\
0.0405\end{array}$ & $\begin{array}{c}-0.0482 \\
0.0451\end{array}$ & $\begin{array}{r}-0.0483 \\
0.0516\end{array}$ \\
\hline $\begin{array}{l}\text { industry median debt } \\
\text { ratio }\end{array}$ & $\begin{array}{c}-0.0488 \\
0.0673\end{array}$ & $\begin{array}{c}-0.1014 \\
0.0710\end{array}$ & $\begin{array}{c}-0.0349 \\
0.0493\end{array}$ & $\begin{array}{c}-0.0859 \\
0.0603\end{array}$ \\
\hline constant & & & $\begin{array}{r}-0.0677 \\
0.0636\end{array}$ & \\
\hline $\mathrm{N}$ & 2653 & 2653 & 3079 & 3079 \\
\hline number of instruments & 451 & 207 & 540 & 234 \\
\hline $\begin{array}{l}\text { Arellano-Bond test for } \\
\text { AR(1) }\end{array}$ & $\begin{array}{c}-8.42 \\
(0.000)\end{array}$ & $\begin{array}{c}-7.66 \\
(0.000)\end{array}$ & $\begin{array}{l}-9.21 \\
(0.000)\end{array}$ & $\begin{array}{c}-8.93 \\
(0.000)\end{array}$ \\
\hline $\begin{array}{l}\text { Arellano-Bond test for } \\
\mathrm{AR}(2)\end{array}$ & $\begin{array}{c}0.53 \\
(0.600)\end{array}$ & $\begin{array}{c}0.61 \\
(0.543)\end{array}$ & $\begin{array}{c}0.60 \\
(0.549)\end{array}$ & $\begin{array}{c}0.59 \\
(0.553)\end{array}$ \\
\hline $\begin{array}{l}\text { Arellano-Bond test for } \\
\operatorname{AR}(3)\end{array}$ & $\begin{array}{c}1.16 \\
(0.246) \\
\end{array}$ & $\begin{array}{c}1.20 \\
(0.231) \\
\end{array}$ & $\begin{array}{c}1.21 \\
(0.225)\end{array}$ & $\begin{array}{c}1.23 \\
(0.217)\end{array}$ \\
\hline $\begin{array}{l}\text { Arellano-Bond test for } \\
\operatorname{AR}(4)\end{array}$ & $\begin{array}{c}-1.08 \\
(0.281)\end{array}$ & $\begin{array}{c}-0.98 \\
(0.327)\end{array}$ & $\begin{array}{c}-0.86 \\
(0.387)\end{array}$ & $\begin{array}{c}-0.84 \\
(0.399)\end{array}$ \\
\hline Sargan test & $\begin{array}{l}472.09 \\
(0.079)\end{array}$ & $\begin{array}{l}223.42 \\
(0.032)\end{array}$ & $\begin{array}{l}612.50 \\
(0.003)\end{array}$ & $\begin{array}{l}301.96 \\
(0.000)\end{array}$ \\
\hline Hansen test & $\begin{array}{l}339.51 \\
(1.000)\end{array}$ & $\begin{array}{r}197.24 \\
(0.272) \\
\end{array}$ & $\begin{array}{c}0.00 \\
(0.000) \\
\end{array}$ & $\begin{array}{l}230.44 \\
(0.183)\end{array}$ \\
\hline
\end{tabular}

Source: Author's own work on.

Note: Year dummies are included in the estimation for all models. ** - significantly different from zero at 0.01 significance level, * - significantly different from zero at 0.05 significance level. 
At 0.05 significance level, estimates for all the models presented in Table 5. suggest significant impact of lagged debt ratio and profitability on companies' debt ratios. Moreover, GMM-DIFF models suggest that size has positive significant impact on debt ratios (although with GMM-DIFF1 only at 0.1 significance level).

In the GMM-DIFF2 model (with lower number of instruments) all the explanatory variables have the same direction of influence on debt ratio as in GMM-DIFF1 model (except for insignificant variable: tangibility of assets). The coefficients for lagged debt ratio and profitability are higher than in GMM-DIFF1, while for size the parameter in question is lower than in GMM-DIFF1 model.

In comparison with basic GMM-DIFF model (estimates reported in Table 4.), the GMMDIFF2 (estimates reported in Table 3.) parameters' estimates were higher for lagged debt ratio and size. It should be noted that the coefficient for size estimated with GMM-DIFF2 constitutes only $8.4 \%$ of the magnitude estimated with GMM-DIFF model.

The parameter with lagged dependent variable is higher for GMM-SYS2 than for GMMSYS1 model. When comparing GMM-SYS2 and GMM-SYS (estimates reported in Table 4.), higher estimates for the former model were obtained for lagged debt ratio.

The differences in magnitude between models estimated with Blundell-Bond (1998) method are smaller than for Arellano-Bond (1991) method. The differences between GMMSYS2 and GMM-SYS1 parameters are the highest for size (-39.5\%).

It should be underlined that according to the results of this study, the direction of impact of selected capital structure determinants is consistent across the GMM models for all significant variables. Lagged dependent variable and size have positive impact on debt ratio, while profitability has negative impact on debt ratio. Nonetheless, the choice of the model might matter as far as direction of the impact for insignificant variables is concerned - as the results of this study shows, the parameter estimates for growth possibilities and tangibility of assets change the sign depending on the chosen estimator.

Comparing standard errors of the parameters, their estimates for all the explanatory variables are higher for GMM-DIFF2 model than for GMM-DIFF1 and GMM-DIFF models (except for insignificant variable: business risk). A similar conclusion can be reached for GMM-SYS2 model in comparison to GMM-SYS1 and GMM-SYS models (all standard errors are the highest for GMM-SYS2 model). At the same time, it should be noted that the standard errors for the GMM-SYS2 model are lower than for GMM-DIFF2 model for all significant independent variables.

As far as instruments' validity tests are concerned, the models presented in Table 3. confirm the existence of autocorrelation of residual differences of first order, as it was observed with GMM-DIFF and GMM-SYS models presented in Table 4. However, this is not a problem, since the estimation was based on explanatory variables lagged two and more periods as instruments (Roodman, 2006). At 0.05 significance level, Hansen test implies the joint validity of overidentifying restrictions. Therefore both GMM-DIFF2 and GMM-SYS2 models can be assessed as valid.

The robustness of the results was verified on the basis of GMM model settings. When the model was estimated without year dummies, business risk and industry median debt ratio had significant negative impact on debt ratios. Moreover, the specification of GMM models could include clustered standard deviations at the sector level. Such a solution influenced only standard errors of the parameters, while the importance of the factors was not affected materially. 
Taking into the consideration autocorrelation of first order identified in both models and joint validity of overidentifying restrictions, GMM-DIFF2 and GMM-SYS2 models are considered as appropriate for assessing the importance of selected determinants of capital structure. However, as estimates of parameter standard errors are lower for GMM-SYS2 than for GMM-DIFF2, the GMM-DIFF2 model is preferred from the econometric point of view. It should though be noted that in GMM-DIFF2 model, the impact of profitability on debt ratio is not significantly different from zero. Therefore for assessing the importance of selected variables from the economic perspective, the consistent results of both GMM-SYS2 and GMM-DIFF2 models should be taken into account. The results of the study in question - i.e. the differences in the set of significant capital structure determinants - support the claim that it is advisable to assess the determinants of capital structure on the basis of set of models instead of relying on a single specification chosen by the researcher.

The positive impact of lagged total debt ratio on total debt ratio of companies is consistent with the predictions of trade-off theory, as well as results of previous studies. Profitability has insignificant negative influence on debt ratio, though the parameter estimate for this variable with different models was significantly different from zero. Negative impact of profitability is against trade-off theory, but in line with the predictions of pecking order theory. The negative impact of profitability was also confirmed by previous research (e.g. Elsas and Florysiak, 2009; Harris and Raviv, 1992; Rajan and Zingales, 1995). The positive impact of size on debt ratios is in accordance with both trade-off theory and pecking order theory. It is also in line with previous research (e.g. Elsas and Florysiak, 2009; Frank and Goyal, 2009; Harris and Raviv, 1992; Rajan and Zingales, 1995).

\section{Conclusions}

The purpose of this article was to analyze the differences in direction and magnitude of selected factors on debt ratios depending on the estimation method used. There were four estimators applied: OLS, FE, GMM-DIFF and GMM-SYS. Taking into account the assumptions of OLS and FE methods, the determinants of capital structure should be analyzed with GMM estimators. Moreover, the validity of GMM models was tested with ArellanoBond test of autocorrelation and Hansen test of instruments' joint validity. The choice of instruments' lags used for GMM models estimation was motivated on the basis of the tests in question.

The results of the study illustrate the importance both selection of the appropriate estimation method and the verification of its assumptions. Although the models presented in this study pointed to the consistent set of factors significantly affecting debt ratios of companies listed on Warsaw Stock Exchange, the magnitude of their impact differed widely between the models. When the debt ratio of the company in the previous period was 0.1 higher, the debt ratio in current period is higher by 0.0441 (FE estimate) to 0.0804 (GMMSYS estimate with instruments' lags 2 to 3 ). When the profitability in previous period was higher by 0.1 , the debt ratio in current period is lower by 0.0058 (GMM-DIFF estimate, all possible instruments' lags) to 0.0124 (GMM-DIFF estimate with instruments' lags 2 and higher). When it comes to size, when in the previous period it was higher by 0.1 , the current debt ratio is higher by 0.0004 (GMM-SYS estimate with instruments' lags 2 to 3) to 0.0040 (GMM-DIFF estimate with instruments' lags 2 to 4). Taking the above into account, the importance of proper model specification cannot be underestimated for the assessment of importance of factors describing company's financial situation.

There are several limitations of the study, which could be used as the basis for further research. Firstly, the study focuses on the differences between selected estimation methods. There was only one set of factors and one set of measures used in the study. Future research 
could analyze the results depending on different set of factors and different measures of the factors chosen for this study. Secondly, the study focused on factors describing financial situation of the companies, while omitting the measures of macroeconomic environment and growth of the economy. Thirdly, the results of this study are based on the data for companies listed on Warsaw Stock Exchange. It could be of interest to compare the results with studies concerning other country or set of countries.

To conclude, it should be noted that the issue of factors affecting capital structure is far from being resolved. Further research in this field should nonetheless pay close attention to the requirements and characteristics of the statistical methods chosen by the researcher, as they might affect the results of the study. As shown by this study concerning capital structure of Polish companies, it is advisable to estimate different models and compare the results in future studies, as the estimation method matters for the magnitude of the impact of the determinants of debt ratio. 


\section{References}

Adrian, M. T, Corporate Finance in Emerging \& Developed Countries-Mixture between Commonality and Heterogeneity Features, Recent Researches in Social Science, Digital Convergence, Manufacturing and Tourism, 69-74, 2010.

Ahn, S. C, and Schmidt, P, Efficient estimation of models for dynamic panel data, Journal of Econometrics, 68(1), 5-27, 1995.

Anderloni, L, and Tanda, A, The Determinants of Leverage: A Comparative Analysis, Journal of Economics and Management, 18, 195, 2014.

Antoniou, A, Guney, Y, and Paudyal, K, The determinants of capital structure: capital market-oriented versus bank-oriented institutions, Journal of Financial and Quantitative Analysis, 43(01), 59-92, 2008.

Arellano, M, and Bond, S, Some tests of specification for panel data: Monte Carlo evidence and an application to employment equations, The Review of Economic Studies, 58(2), 277-297, 1991.

Baltagi, B, Econometric analysis of panel data, John Wiley and Sons, 2008.

Barowicz, M, Determinanty struktury kapitałowej w teorii uwzględniającej rynek produktów, Ekonomika i Organizacja Przedsiębiorstwa, (11), 20-33, 2012.

Barowicz, M, Determinanty struktury kapitałowej w teorii cyklu życia przedsiębiorstwa, Ekonomika i Organizacja Przedsiębiorstwa, (5), 3-13, 2013.

Białek-Jaworska, A, and Nehrebecka, N, Determinants of Polish Companies' Debt Financing Preferences, Social Sciences, 87(1), 19-32, 2015.

Blundell, R, and Bond, S, Initial conditions and moment restrictions in dynamic panel data models, Journal of Econometrics, 87(1), 115-143, 1998.

Chang, X, and Dasgupta, S, Target behavior and financing: how conclusive is the evidence?, The Journal of Finance, 64(4), 1767-1796, 2009.

Chang, Y. K, Chou, R. K, and Huang, T. H, Corporate governance and the dynamics of capital structure: New evidence, Journal of Banking and Finance, 48, 374-385, 2014.

Kubiak, J. J, and Czapiewski, L, The Impact of Information Asymmetry on the Use of Short-term Debt in Selected European States, Folia Oeconomica, 1(310), 2015.

Dang, V. A, Kim, M, and Shin, Y, Asymmetric capital structure adjustments: New evidence from dynamic panel threshold models, Journal of Empirical Finance, 19(4), 465-482, 2012.

Deesomsak, R, Paudyal, K, and Pescetto, G, Debt maturity structure and the 1997 Asian financial crisis, Journal of Multinational Financial Management, 19(1), 26-42, 2009.

Delcoure, N, The determinants of capital structure in transitional economies, International Review of Economics \& Finance, 16(3), 400-415, 2007.

Devic, A, and Krstic, M, Comparable analysis of the capital structure determinants in Polish and Hungarian enterprises-empirical study, Economics and Organization, 1(9), 85-100, 2001.

de Haas, R. T. A, and Peeters, H. M. M, Firms' dynamic adjustment to target capital structures in transition economies, WO Research Memoranda (discontinued), 761, 2004.

De Jong, A, Kabir, R, and Nguyen, T. T, Capital structure around the world: The roles of firm-and country-specific determinants, Journal of Banking and Finance, 32(9), 1954-1969, 2008. 
Elsas, R, and Florysiak, D, Empirical capital structure research: New ideas, recent evidence, and methodological issues, Munich School of Management Discussion Paper, (2008-10), 2008.

Farhat, J. B, Cotei, C, and Abugri, B. A, Testing trade-off and pecking order models under different institutional environments, available at SSRN 1404596, 2009.

Faulkender, M, Flannery, M. J, Hankins, K. W, and Smith, J. M, Cash flows and leverage adjustments, Journal of Financial Economics, 103(3), 632-646, 2012.

Flannery, M. J, and Hankins, K. W, Estimating dynamic panel models in corporate finance, Journal of Corporate Finance, 19, 1-19, 2013.

Flannery, M. J, and Rangan, K. P, Partial adjustment toward target capital structures, Journal of Financial Economics, 79(3), 469-506, 2006.

Frank, M. Z, and Goyal, V. K, Capital structure decisions: which factors are reliably important?, Financial Management, 38(1), 1-37, 2009.

Gajdka, J, Teorie struktury kapitału i ich aplikcja w warunkach polskich, Wydaw. Uniwersytetu Łódzkiego, 2002.

Gao, W, and Zhu, F, Information asymmetry and capital structure around the world, Pacific-Basin Finance Journal, 32, 131-159, 2015.

Hahn, J, Hausman, J, and Kuersteiner, G, Long difference instrumental variables estimation for dynamic panel models with fixed effects, Journal of Econometrics, 140(2), 574-617, 2007.

Haron, R. Capital structure inconclusiveness: evidence from Malaysia, Thailand and Singapore, International Journal of Managerial Finance, 10(1), 23-38, 2014.

Harris, M, and Raviv, A, Financial contracting theory, in: Advances in economic theory: sixth world congress (Vol. 2, pp. 64-150), Cambridge Univ. Press Cambridge, 1992

Hovakimian, A, Hovakimian, G, and Tehranian, H, Determinants of target capital structure: The case of dual debt and equity issues, Journal of Financial Economics, 71(3), 517-540, 2004.

Huang, R, and Ritter, J. R, Testing theories of capital structure and estimating the speed of adjustment, Journal of Financial and Quantitative analysis, 44(02), 237-271, 2009.

Hurlin, C, Dynamic panel data models, materials for the lecture at University of Geneva, www.univorleans.fr/deg/masters/ESA/CH/Geneve_Chapitre2.pdf, accessed 25.10.2016, 2010.

Jędrzejczak-Gas, J, Struktura kapitału w małych i średnich przedsiębiorstwach, Zeszyty Naukowe Uniwersytetu Szczecińskiego. Finanse. Rynki finansowe. Ubezpieczenia, (62), 583-593, 2013.

Jõeveer, K, Firm, country and macroeconomic determinants of capital structure: Evidence from transition economies, Journal of Comparative Economics, 41(1), 294-308, 2013.

Kayhan, A, and Titman, S, Firms' histories and their capital structures, Journal of Financial Economics, 83(1), 1-32, 2007.

Klapper, L. F, Sarria-Allende, V, and Zaidi, R, A firm-level analysis of small and medium size enterprise financing in Poland', World Bank Policy Research Working Paper No. 3984, 2006.

Kumar, S, Kumar, S, Colombage, S, Colombage, S, Rao, P, \& Rao, P, Research on capital structure determinants: a review and future directions, International Journal of Managerial Finance, 13(2), 106-132, 2017. 
La Rocca, M, La Rocca, T, Gerace, D, and Smark, C, Effect of diversification on capital structure, Accounting and Finance, 49(4), 799-826, 2009.

Lemma, T, and Negash, M, Determinants of the adjustment speed of capital structure: Evidence from developing economies, Journal of Applied Accounting Research, 15(1), 64-99, 2014.

Leary, M. T, and Roberts, M. R, Do firms rebalance their capital structures?, The Journal of Finance, 60(6), 2575-2619, 2005.

Lemmon, M. L, Roberts, M. R, and Zender, J. F, Back to the beginning: persistence and the crosssection of corporate capital structure, The Journal of Finance, 63(4), 1575-1608, 2008.

Lucas, D. J, and McDonald, R. L, Equity issues and stock price dynamics, The journal of Finance, 45(4), 1019-1043, 1990.

MacKay, P, and Phillips, G. M, How does industry affect firm financial structure?, Review of Financial Studies, 18(4), 1433-1466, 2005.

Mazur, K, The determinants of capital structure choice: evidence from Polish companies, International Advances in Economic Research, 13(4), 495-514, 2007.

Motylska-Kuźma, A, Akcjonariat a struktura kapitału w spółkach notowanych na GPW, Zeszyty Naukowe Uniwersytetu Szczecińskiego. Finanse. Rynki finansowe. Ubezpieczenia, (62), 753-763, 2013.

Myers, S. C, and Majluf, N. S, Corporate financing and investment decisions when firms have information that investors do not have, Journal of Financial Economics, 13(2), 187-221, 1984.

Myers, S. C, Financing of corporations, Handbook of the Economics of Finance, 1, 215-253, 2003.

Myers, S. C, The capital structure puzzle, The Journal of Finance, 39(3), 574-592, 1984.

Nickell, S, Biases in dynamic models with fixed effects, Econometrica: Journal of the Econometric Society, 1417-1426, 1981.

Ozkan, A, Determinants of capital structure and adjustment to long run target: evidence from UK company panel data, Journal of Business Finance and Accounting, 28(1-2), 175-198, 2001.

Öztekin, Ö, and Flannery, M. J, Institutional determinants of capital structure adjustment speeds, Journal of Financial Economics, 103(1), 88-112, 2012.

Prędkiewicz, K, and Prędkiewicz, P, Patenty a struktura kapitału-badania w przedsiębiorstwach produkcyjnych w latach 2004-2012, Zeszyty Naukowe Uniwersytetu Szczecińskiego. Finanse. Rynki finansowe. Ubezpieczenia, (74 T. 1 Rynek kapitałowy, wycena przedsiębiorstw, inwestycje), 377-386, 2015.

Rajan, R. G, and Zingales, L, What do we know about capital structure? Some evidence from international data, The Journal of Finance, 50(5), 1421-1460, 1995.

Rashid, A, Firm external financing decisions: explaining the role of risks, Managerial Finance, 40(1), 97-116, 2014.

Roodman, D, How to do xtabond2: An introduction to difference and system GMM in Stata, Center for Global Development Working Paper, (103), 2006.

Santos, M. S, Moreira, A. C, and Vieira, E. S, Ownership concentration, contestability, family firms, and capital structure, Journal of Management and Governance, 18(4), 1063-1107, 2014. 
Shyam-Sunder, L, and Myers, S. C, Testing static tradeoff against pecking order models of capital structure, Journal of Financial Economics, 51(2), 219-244, 1999.

Siedlecki, R, Teorie struktury kapitału a cykl życia przedsiębiorstwa. Prace Naukowe Uniwersytetu Ekonomicznego we Wrocławiu, (261), 381-389, 2012.

Socha, B, Struktura finansowania polskich firm rodzinnych w kontekście nadzoru właścicielskiegoraport z badań, Zeszyty Naukowe Uniwersytetu Szczecińskiego. Finanse. Rynki finansowe. Ubezpieczenia, (73 Ryzyko, zarządzanie, wartość), 265-277, 2015.

Weill, L, Determinants of Leverage and Access to Credit: Evidence on western and Eastern Europe countries. Research in banking and finance, 2, 319-339, 2002.

Welch, I, Capital structure and stock returns, Journal of Political Economy, 112(1), 106-132, 2004.

Wintoki, M. B, Linck, J. S, and Netter, J. M, Endogeneity and the dynamics of internal corporate governance. Journal of Financial Economics, 105(3), 581-606, 2012. 